\title{
First report of partial albinism in the blue lobster Panulirus inflatus (Bouvier, 1895) from the Mexican Pacific (Crustacea, Decapoda, Palinuridae)
}

\author{
Victor Landa-Jaime', Bernabé Aguilar-Palomino', \\ Jesús Emilio Michel-Morfín', Mirella Saucedo Lozano' \\ I Departamento de Estudios para el Desarrollo Sustentable de Zonas Costeras, Universidad de Guadalajara
} Gómez Farias 82, San Patricio-Melaque, Jalisco, C.P. 48980 Mexico

Corresponding author: Victor Landa-Jaime (victor.landa@academicos.udg.mx)

Academic editor: I. Wehrtmann | Received 16 March 2018 | Accepted 21 July 2018 | Published 12 September 2018

http://zoobank.org/47663D69-75F9-48EA-B221-778C729C012C

Citation: Landa-Jaime V, Aguilar-Palomino B, Michel-Morfín JE, Lozano MS (2018) First report of partial albinism in the blue lobster Panulirus inflatus (Bouvier, 1895) from the Mexican Pacific (Crustacea, Decapoda, Palinuridae). ZooKeys 784: 1-6. https://doi.org/10.3897/zookeys.784.25082

\begin{abstract}
The first case of partial albinism registered in the Mexican Pacific by the blue lobster Panulirus inflatus is presented. The specimen was collected on the southern coast of Jalisco know as Punta "El Estrecho". It constitutes one of the few registered cases of albinism in invertebrates from the Eastern Tropical Pacific.
\end{abstract}

\section{Keywords}

crustaceans, Eastern Tropical Pacific, Palinuridae, Spiny Lobster, western America

\section{Introduction}

Albinism is a genetic condition, the result of a mutation on the gene that codifies the enzyme tirosinase, and results in losing the capacity to synthetize melanin, the same pigment that is responsible for the color of skin and hair in animals; therefore the anomaly causes the organisms to adopt a white coloration on the skin and hair and have red eyes (Griffiths et al. 2000). According to the phenotypic characteristic of the individuals, this type of mutation can be expressed in four ways: a) albinism, which is the complete loss of pigmentation throughout the body, b) dilution, where

Copyright Victor Landa-Jaime et al. This is an open access article distributed under the terms of the Creative Commons Attribution License (CC BY 4.0), which permits unrestricted use, distribution, and reproduction in any medium, provided the original author and source are credited. 
the tonality of the color is reduced as well as other natural pigments, c) squizocroism where the pigment is not expressed but does not affect any other pigments, and d) leucism that is translated in the loss of color of the skin and hair without affecting the soft parts (Buckley 1982). In the latter case, the animals present white skin and hair (Miller 2005, Garcia-Morales et al. 2010). This condition has been recorded in different groups of marine animals like echinoderms (Kehas et al. 2005, Fernández-Rivera et al. 2015), crustaceans (James 2005), fishes (Evangelista-Leal et al. 2013), and sharks (Sancho-Vazquez et al. 2015). Chromatic anomalies have also been registered such as partial albinism, which involve the lack of pigmentation of different body regions (Sancho-Vazquez et al. 2015).

Panulirus is a genus that includes representatives of species knows as spiny, rock, or blue lobsters. Most species of the genus have a large worldwide commercial importance (Holthuis 1991, Hendrickx 1995). The blue lobster, P. inflatus (Bouvier, 1895), which constitutes the object of this contribution, is frequently observed on rocky reefs with crystalline waters and to $30 \mathrm{~m}$ depth (Briones-Fourzan and Lozano-Alvarez 2003). The species is considered to be endemic to the west coast of Mexico, within a specific geographic range from Bahia Magdalena, Baja California, to the Gulf of Tehuantepec, Oaxaca, Mexico (Butler et al. 2011).

\section{Materials and methods}

A specimen of Panulirus inflatus was collected from the coastal waters on a site known as Punta El Estrecho, on the southern coast of the state of Jalisco, Mexico $\left(19^{\circ} 06^{\prime} 11^{\prime \prime N}\right.$; $104^{\circ} 29^{\prime} 12^{\prime \prime W}$; Figure 1). The specimen was captured using the hook fishing technique during night submersions at a depth of $15 \mathrm{~m}$ on predominantly rocky bottoms using scuba diving on 05 July 2016.

Due to the peculiar characteristics of the specimen, the fisherman who captured it donated the individual to the Universidad de Guadalajara. The specimen was identified using specialized literature (Holthuis 1991, Hendrickx 1995) and preserved in formaldehyde at $10 \%$ for a week. The specimen was then washed and transferred to a permanent container in 70\% alcohol in the local Invertebrates Collection assigning the following catalogue number: CIDEDSZC1008.

\section{Results}

The specimen examined was a male with a total length of $24 \mathrm{~cm}$ and a weight of $300 \mathrm{~g}$. Other measurements taken included: length and width of the cephalothorax $9 \mathrm{~cm}$ and $6 \mathrm{~cm}$; length and width of the tail $11 \mathrm{~cm}$ and $6 \mathrm{~cm}$; length and width of the claw $4 \mathrm{~cm}$ and $3 \mathrm{~cm}$.

Lack of pigmentation was observed on different parts of the body and appendages. Appendages lacking pigments included the flagella of the right and left antennules, the 


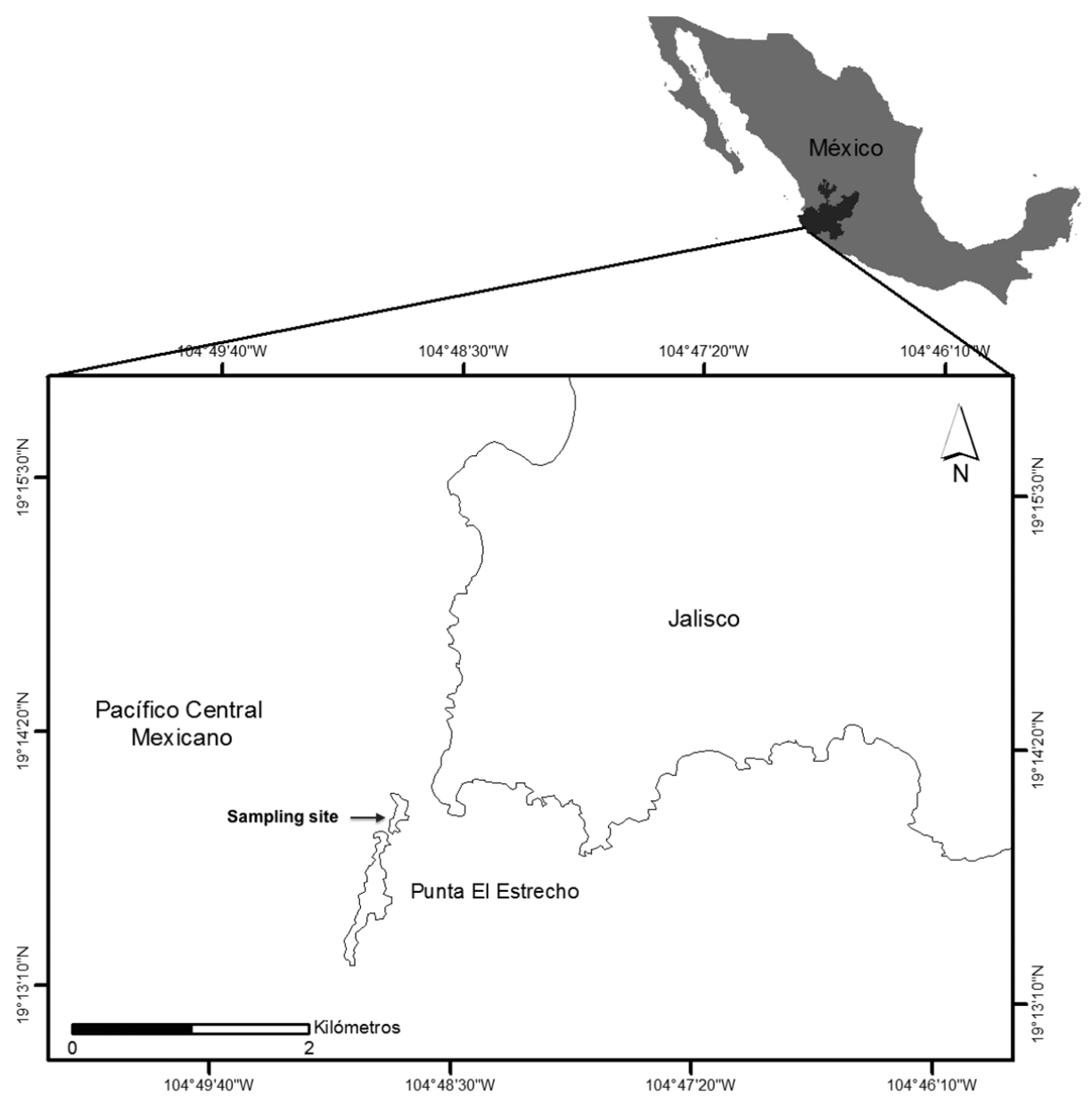

Figure I. Map of the sampling area, Punta El Estrecho, Jalisco, México.

right antenna, the left and right chelipeds, and all pereiopods (Figure 2a). The abdominal somites III and V were partly devoid of pigmentation dorsally and somites III to VI lacked pigmentation ventrally (Figs. 2b, c). The cephalothorax lacked pigment only on the ventral part (Figure 2c). The third left pleopod was partially pigmented and pairs of pleopods IV-VI lacked pigmentation (Figure 2c). The telson partially lacked pigmentation on the dorsal and totally on ventral side (Figure 2b, c).

\section{Discussion}

The albinism phenomenon has been reported on vertebrates, and elasmobranches. However, the data are scarce regarding invertebrates (Fernández-Rivera et al. 2015). 

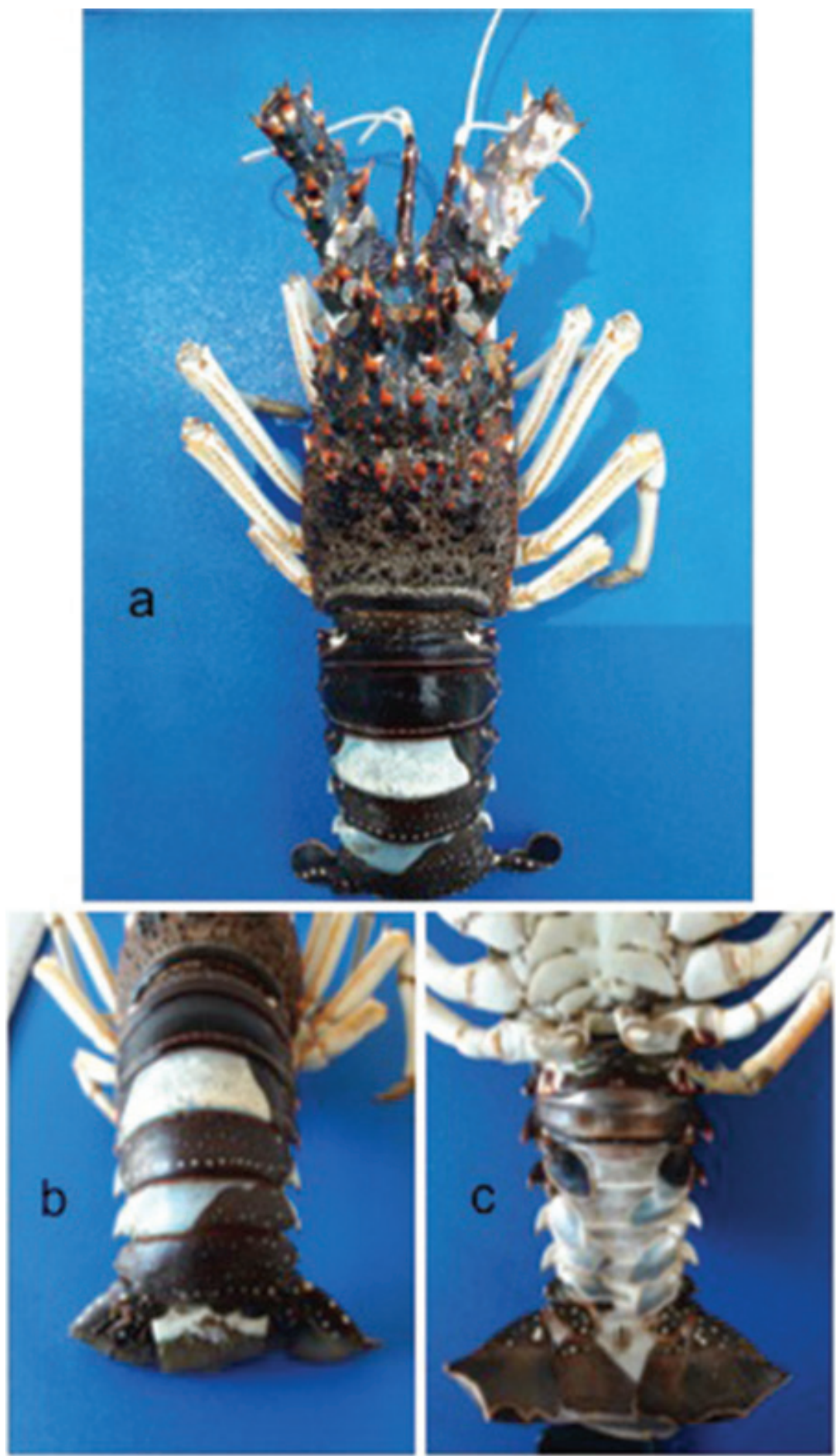

Figure 2. Blue Lobster Panulirus inflatus. a Complete dorsal view b Partial dorsal view c Partial ventral view. 
Isolated cases of albinism on invertebrates have been reported by Kehas et al. (2005) in the land snail Planorbella trivolvis, James (2005) observed this phenomenon in juveniles of crabs Cancer pagurus, and Fernández-Rivera et al. (2015) found two specimens with albinism of sea cucumber Isostichopus fuscus in the Gulf of California, México. As far as we know, the only reported case of albinism in lobsters refers to Panulirus japonicus (Okamoto and Misyuku 1998).

According to Evangelista-Leal et al. (2013), the occurrence of albinism in fishes can be caused by three factors: random genetic alteration, an effect of marine pollution, or genetic alterations due to the size of the populations. Further studies are required in different species displaying albinism to understand the factors that cause this phenomenon and to evaluate if abnormal pigmentation can be used as an indicator of the quality of the habitat or populations in special situations. In benthic organisms such as species of crustaceans, pigmentation of the body is a vital factor for survival because the organisms use camouflage to avoid predators, when it confused with other animals or their environment (Tan and Richer De Forges 1993).

It must be highlighted that during the previous year in which the specimen was captured an event of the El Niño South Oscillation in the Mexican tropical Pacific occurred (National Oceanic and Atmospheric Administration 2015, Jacox et al. 2016); however, there is no evidence to associate the observed albinism to this oceanographic situation.

\section{Acknowledgements}

The authors are grateful to J. Osiel Arteaga Aguilar, the scuba diver for it's generous donation of the specimen to the invertebrate collection of the DEDSZC-CUCSUR of the University of Guadalajara. We are also grateful to Alejandra Valdez Cibrian for drawing the map and Ramiro Flores Vargas for his editorial assistance.

\section{References}

Briones-Fourzan P, Lozano-Alvarez E (2003) Factors affecting growth of the Spiny lobsters Panulirus gracilis and Panulirus inflatus (Decapoda: Palinuridae) In Guerrero, México. Revista de Biología Tropical 51: 165-174.

Buckley PA (1982) Avian genetics. In: Petrak M (Ed.) Diseases of Cage and Aviary Birds. Lea $\&$ Febiger Press, Philadelphia, 21-110.

Butler M, Cockroft A, MacDiarmid A (2011) Panulirus inflatus. The IUCN Red List of Threatened Species 2011: T169993A6701255. http://dx.doi.org/10.2305/IUCN.UK.RLTS. T169993A6701255

Evangelista-Leal M, Schulz HU, Lehmann-Albornoz P, Machado R, Ott PH (2013) First record of partial albinism in two catfish species of Genidens (Siluriformes: Ariidae) in an estuary of Southern Brazil. Brazilian Archives of Biology and Technology 56(2): 237-240. https://doi.org/10.1590/S1516-89132013000200008 
Fernández-Rivera M, Reyes-Bonilla H, Cantú A, Urías J (2015) First record of albinism in the brown sea cucumber Isostichopus fuscus in the Gulf of California, México. Marine Biodiversity Records 8: e14. http://dx.doi.org/10.1017/S1755267214001353

Garcia-Morales R, Gordillo-Chávez EJ, Bello-Gutiérrez J (2010) Primer registro de albinismo en Glossophaga soricina (Phyllostomidae) en México. Chiroptera Neotropical 16(2): 743-747.

Griffiths AJF, Miller JH, Suzuki DT, Lewontin RC, Gelbart WM (2000) An Introduction to Genetic Analysis, $7^{\text {th }}$ ed. WH Freeman $\&$ Co Press, New York, 706 pp.

Hendrickx M (1995) Langostas. In: Fischer W, Krupp F, Schneider W, Sommer C, Carpenter KE, Niem VH (Eds) Guía FAO para la identificación de especies para los fines de la pesca. Pacífico Centro-oriental. Volumen I. Plantas e Invertebrados. FAO, Roma, 384-415.

Holthuis LB (1991) FAO Species catalogue. Vol. 13. Marine lobsters of the world. An annotated and illustrated catalogue of species of interest to fisheries known to date. FAO Fisheries Synopsis. No. 125, Vol. 13. FAO, Rome, 1-292.

Jacox MG, Hazen EL, Zaba KD, Rudnick DL, Edwards CA, Moore AM, Bograd SJ (2016) Impacts of the 2015-2016 El Niño on the California Current System: Early assessment and comparison to post events. Geophysical Research Letters 43(13): 7072-7080.

James JG (2005) Albinism in the edible crab, Cancer pagurus (Decapoda: Brachyura). Crustaceana 35(1): 105-106. https://doi.org/10.1163/156854078X00312

Kehas AJ, Theoharides EKA, Gilbert JJ (2005) Effect of sunlight intensity and albinism on the covering response of the Caribbean sea urchin Tripneustes ventricosus. Marine Biology 146: 1111-1117. http://dx.doi.org/10.1007/s00227-004-1514-4

Miller JD (2005) All about albinism. Missouri Conservationist 66(6): 4-7.

National Oceanic and Atmospheric Administration (NOAA) (2015) Relevant news. http://coralreefwatch.noaa.gov/satellite/index.php [accessed 05/15/2016]

Okamoto K, Misyuku A (1998) Molting and growth of the albino Spiny lobsters Panulirus japonicus collected from southern coast of the Peninsula, Shizuoka prefecture. Cancer 7: 17-18.

Sancho-Vazquez F, Del Moral-Flores LF, Mendoza-Vargas OU (2015) Albinismo parcial en un embrión de tiburón puntas negras, Carcharhinus limbatus (Carcharhinidae: Chondrichthyes) del Pacífico oriental. Latin American Journal of Aquatic Research 43(1): 274-27. https://doi.org/10.3856/vol43-issue1-fulltext-25

Tan CGS, Richer De Forges B (1993) On the systematics and ecology of two species of mimetic crabs belonging to the family Leucosidae (Crustacea: Decapoda: Brachyura). Raffles Bulletin of Zoology 41(1): 119-132. 